\title{
Controlling the dominant follicle in beef cattle to improve estrous synchronization and early embryonic development
}

\author{
ML Day', ML Mussard', GA Bridges ${ }^{2}$ and CR Burke ${ }^{3}$ \\ 'Department of Animal Sciences, The Ohio State University, Columbus OH USA 43210; 'North \\ Central Research and Outreach Center, University of Minnesota, Grand Rapids, MN, USA; ${ }^{3}$ DairyNZ \\ Limited, Hamilton 3240. New Zealand
}

Estrous synchronization and timed ovulation programs that permit $\mathrm{Al}$ at a predetermined time (timed $\mathrm{Al}$ ) rather than as determined by detection of spontaneous estrus are requisite for increased adoption of $\mathrm{Al}$ in the beef cattle industry. In the past two decades, significant progress has been achieved in developing programs that synchronize ovulation to address this need. While this progress has been driven by a multitude of fundamental discoveries in reproductive biology, the greatest impact in the past two decades has been the result of enhanced understanding of the pattern of ovarian follicle growth in cattle and development of technologies to coordinate growth and ovulation of the dominant follicle. At present, estrous synchronization programs that result in acceptable timed $\mathrm{Al}$ pregnancy rates are available for beef cattle. The capacity to control growth of the dominant follicle and evaluate the impact of various approaches on fertility has resulted in greater understanding of the factors that influence maturity of ovulatory follicles. Modifications to the standard industry breeding programs, with the aim of lengthening and/or increasing the gonadotropic stimulus and estradiol production by preovulatory follicles, have been shown to substantially increase timed Al pregnancy rate in beef cattle. Associations between characteristics of follicular development and fertility have surfaced from application of estrous and ovulation synchronization technologies and led to investigation of the fundamental mechanisms that underlie these relationships.

\section{Introduction}

Effective estrous synchronization technologies to facilitate the use of timed $\mathrm{Al}$ in beef cattle have been developed (Larson et al, 2006; Sa Filho et al., 2009) and modifications that enhance their efficacy (Bridges et al., 2009; Meneghetti et al., 2009) continue to be discovered (Figure 1). The current technologies reflect the culmination of relevant fundamental discoveries in reproductive physiology that date to the early 1900 s, and research in estrous synchronization that has been ongoing for over 60 years. The rapid progress in the field of estrous synchronization and timed Al over the last two decades can be directly linked to the discovery of a wave-like pattern of follicular development in cattle (Savio et al., 1988; Sirois and Fortune, 
1988; Ginther et al., 1989). Since that time, research has progressed through investigation of the implications of not controlling follicular development, approaches to coordinate follicle development and application of methodology to control growth and ovulation of the dominant follicle in conjunction with other components of estrous synchronization and timed Al programs. The synchronization programs currently used in cattle reflect only a portion of the valuable knowledge gained through this area of research. Through attempts to coordinate follicular development and standardize the timing of ovulation, greater understanding of the impact of variation in follicular development on fertility in cattle has evolved. Various relationships between fertility in cattle and aspects of follicular development, such as follicle size, length of proestrus, follicular estradiol production, and progesterone concentrations during follicular development to fertility in cattle have emerged, and led to fundamental investigations of the mechanisms that underlie these associations.

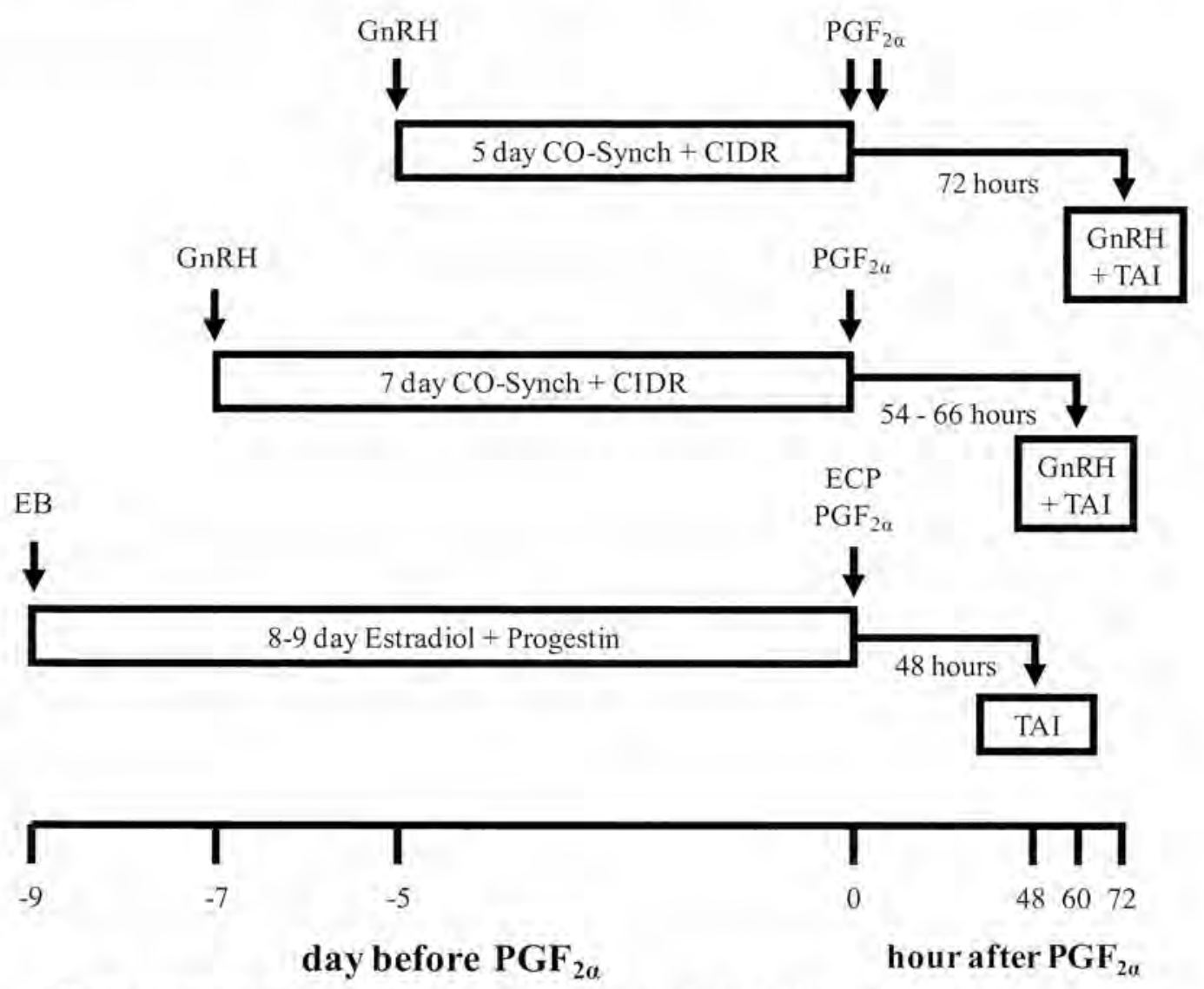

Fig. 1. Common estrous synchronization programs used with timed Al in postpartum beef cows. $\mathrm{GnRH}=$ gonadotropin releasing hormone; $\mathrm{PGF}_{2 \alpha}=$ prostaglandin $\mathrm{F}_{2 \alpha^{\prime}}$ CIDR $=$ Controlled Internal Drug Release Insert; $\mathrm{EB}=$ estradiol benzoate; $\mathrm{ECP}=$ estradiol cypionate; $T A I=$ timed $A I$. With the GnRH-based programs in the USA, the CIDR ${ }^{*}$ is the only available progestin source. With Estradiol + Progestin systems, varying forms of estradiol are used at the start of the progestin treatment. Also timing of PGF ${ }_{20}$, form and timing of estradiol used to synchronize ovulation, interval to timed $\mathrm{Al}$ and source of progestin vary among programs. 


\section{Traditional approaches to estrous cycle control in cattle}

Early attempts to synchronize estrus in cattle were based on the knowledge that progesterone prevents the occurrence of estrus and ovulation (Christian and Casida, 1948). A variety of progestins were administered in an assortment of methods to attempt to coordinate the timing of estrus in cattle (Trimberger and Hansel, 1955; Zimbelman and Smith, 1966). Progestin treatments of relatively long duration resulted in the most precise timing of estrus since this allowed for spontaneous occurrence of luteolysis during progestin treatment, but fertility was substantially less than would be expected following a spontaneous estrus (Zimbelman et al., 1970; Wishart, 1977). The inverse relationship between duration of progestin treatment and fertility led to development of short-term progestin treatments.

One approach to shortening the duration of progestin treatment was administration of a pharmacological dose of estrogen at the initiation of treatment to induce luteal regression; rather than relying on long-term treatments to allow spontaneous luteolysis (Wiltbank and Kasson, 1968; Mauleon, 1974). Synchrony of estrus and fertility varied with these approaches since the response to estrogen varied by stage of the estrous cycle (Lemon, 1975; Miksch et al., 1978). Development of short-term programs was also aided by identification of $\mathrm{PGF}_{2 \alpha}$ as a luteolysin (McCracken et al., 1972) and characterization of its efficacy to induce luteolysis (Lauderdale, 1975). However, the timing of estrus after utilizing this approach continued to vary (Wishart, 1974; Thimonier et al., 1975) due to stage of the estrous cycle at which luteal regression was induced (King et al., 1982), and fertility varied due to the stage of the estrous cycle when progestin treatment was initiated (Beal et al., 1988). Although usable estrous synchronization programs existed at this time, the efficacy of most programs was not predictable (Odde, 1990, review).

\section{Coordinating follicular growth for estrous synchronization}

\section{Persistent ovarian follicles}

Characterization of the wave-like pattern of follicular growth in cattle through the use of ovarian ultrasonography (Savio et al., 1988; Sirois and Fortune, 1988; Ginther et al., 1989) provided insight into challenges associated with earlier approaches to synchronize estrus. Although it had been known for some time that ovarian follicular development was not a random event in cattle (Rajakoski, 1960), controlling this aspect of ovarian function was not an intentional component of most programs. With new insight on the normal pattern of follicular growth and ultrasonographic capabilities, it was demonstrated that administration of a progestin in the absence of a corpus luteum extended the lifespan of the dominant ovarian follicle until the progestin was withdrawn (Sirois and Fortune, 1990). Dominant ovarian follicles with an extended lifespan ('persistent follicles') were shown to develop when practically any type of progestin was administered in the absence of a corpus luteum (Stock and Fortune, 1993; Anderson and Day, 1994), resulting in increased frequency of LH pulses and concentrations of estradiol (Kinder et al., 1996, review). Fertility was reduced if the lifespan of a dominant follicle was prolonged for four days (Mihm et al., 1994) and while fertilization of oocytes was unaffected, the embryo died shortly thereafter (Ahmad et al., 1995). Since the need of a progestin for synchronization of estrus in beef cattle has been well documented (Day, 2004, review), subsequent research focused on preventing ovulation of persistent follicles at the synchronized estrus. 


\section{Coordinating follicular development through management of persistent follicles}

The discovery that atresia of persistent follicles could be induced by acutely increasing peripheral progesterone concentrations (Stock and Fortune, 1993; Savio et al., 1993), resulting in synchronous emergence of a new follicular wave 3.5 later (Anderson and Day, 1994) provided a potential tool that could be used to manipulate follicular development for estrous synchronization and avoid the infertility inherent to ovulation of persistent follicles. McDowell et al. (1998a) demonstrated that 24 hours of exposure to mid-luteal progesterone concentrations was sufficient to induce atresia of persistent follicles.

The concept of using progesterone delivered via an injection to synchronize atresia of persistent ovarian follicles and coordinate follicular development in herds of cattle was evaluated in a series of experiments (Anderson and Day, 1994, 1998; McDowell et al., 1998b). Experiments varied by progestin source and duration and the use of $\mathrm{PGF}_{2 x}$ to induce luteal regression. Conclusions from this series of experiments were that induced atresia of persistent follicles with progesterone resulted in a synchronous and fertile estrus and provided a means to coordinate follicular development in cows at random stages of the estrous cycle and in anestrous cows. A limitation of this approach for estrous synchronization was duration of treatment ( $\geq 14$ days) necessary to ensure that most females initially developed persistent follicles. Synchronization programs that exceed 10 days are not acceptable to most producers. Furthermore, injectable progesterone is not commercially available in the USA.

Infertility associated with long term progestin use and development of persistent follicles can be avoided if cattle are not inseminated at the first estrus after progestin withdrawal but are inseminated at a subsequent synchronized estrus. Initial investigation of this approach involved feeding of an oral progestin for 14 days and induction of luteolysis with PGF $_{20} 17$ days later (Brown et al., 1988). This presynchronization with a progestin takes advantage of the beneficial effects of progestins and passively coordinates follicular development since a majority of females are in a similar stage of the estrous cycle at the time of $\mathrm{PGF}_{2 n}$-induced luteal regression. This approach has been further refined (Lamb et al., 2000; Mallory et al., 2010) and effectively synchronizes estrus in cattle. The interval from initiation of progestin treatment to $\mathrm{Al}$ with this approach ranges from 33 to 36 days.

\section{Coordination of follicular development with estradiol}

An alternative to managing persistent follicles to coordinate growth of the dominant follicle would be to 'reset' follicular development at the outset of an estrous synchronization program and avoid development of persistent follicles altogether. Early evidence that estrogens may function in this manner was that injection of estradiol valerate induced atresia of large ovarian follicles (Engelhardt et al., 1989). It was subsequently demonstrated that injection of estradiol $17 B$ induced atresia of the dominant follicle of the first follicular wave resulting in emergence of a new follicular wave approximately four days later in all females (Bo et al., 1995) thus providing a valuable tool to control growth of the dominant follicle for estrous synchronization. Several studies have focused on understanding the variation and mechanisms associated with the use of estradiol to reset follicular development using estradiol benzoate (EB; see Day and Burke, 2002 for review). Intramuscular injection of EB consistently induced atresia of dominant follicles and resulted in emergence of a new follicular wave (Burke et al., 2000, 2001), interval from EB to emergence of the new follicular wave increased with dose and EB was effective across stages of the estrous cycle (Day and Burke, 2002). The conception rate of cows administered EB at the initiation of progestin treatment was similar to that of cows exhibiting a spontaneous estrus (Day et al., 2000). Further, it was demonstrated that sustained 
concentrations of progesterone, for a minimum of $48 \mathrm{~h}$, were necessary for EB to consistently reset follicular development (Burke et al., 1998).

In intact cows, administration of EB during the luteal phase suppressed $\mathrm{LH}$ and/or FSH in the periphery and induced an immediate decline in estradiol production by dominant follicles through suppression of aromatase (Burke et al., 2005; 2007). Timing of emergence of the new wave of follicular development was dependent upon the duration of FSH suppression by the exogenously administered estradiol and was dose dependent (Burke et al., 2003). These findings, and others (not cited) clearly established that the administration of exogenous estradiol represents a predictable and highly effective method to coordinate growth of the dominant follicle for estrous synchronization and timed $\mathrm{Al}$ in cattle.

\section{Coordination of follicular development with GnRH}

A second method to reset follicular development at the outset of an estrous synchronization program is the use of $\mathrm{GnRH}$ or its agonists. Injection of $\mathrm{GnRH}$ induces an $\mathrm{LH}$ surge within 2 hours (Kaltenbach et al., 1974) and, within 1 to 2 days, there is a reduction in the number of large follicles (Thatcher et al., 1989) due to ovulation and subsequent formation of a new corpus luteum (Twagiramungu et al., 1994). Synchronized emergence of a new follicular wave after GnRH (Macmillan and Thatcher, 1991) occurred within 1 to 2 days after GnRH injection (Twagiramungu et al., 1994, 1995).

A challenge of using GnRH for estrous synchronization is that ovulation in response to the first $\mathrm{GnRH}$ is induced in only $66 \%$ of beef cows (Geary et al, 2000). In heifers, response rates approaching 50\% have been reported (Pursley et al., 1995). Variation in response to GnRH has been attributed to day of the estrous cycle (Moreira et al., 2000) and the influence of day of the estrous cycle on ovulatory response and growth of newly emerged dominant follicles in cows and heifers has recently been investigated (Atkins et al., 2008, 2010). Estrous synchronization programs that use GnRH should be structured to minimize the negative impact of uncoordinated follicular development that occurs in 20 to $50 \%$ of females treated.

\section{Estrous synchronization programs for timed AI in beef cows}

The capacity to coordinate growth of the dominant follicle stimulated a period of intense investigation that led to development of programs currently used for estrous synchronization in beef cattle. The importance of these contributions is recognized, but the focus here is on the current programs used for timed Al in beef cows, their benefits and shortcomings, and ongoing research to improve the current methodology.

\section{Strategy of current timed Al programs}

In beef cows, timed Al programs include a progestin source to suppress estrus and for induction of estrous cycles in anestrous females, and $\mathrm{PGF}_{2 \alpha}$ to induce luteal regression (Figure 1). In the USA, GnRH or its agonist is used to reset follicular development at the initiation of the synchronization program and at the end of the program to synchronize ovulation for timed Al. In many other countries estradiol (either 17ß-estradiol or estradiol benzoate) is used in timed-Al to reset follicular development and estradiol (including estradiol cypionate) is again used at the end of the program to synchronize ovulation. 
Regardless of whether programs are GnRH- or estradiol-based, the rationale for the design of current programs is similar. Treatments begin with insertion of an intravaginal progestin device that is accompanied by $\mathrm{GnRH}$ or estradiol to reset follicular development. Emergence of a new follicular wave occurs 1 to $2(\mathrm{GnRH})$ or 3 to 4 (estradiol) days later. When $\mathrm{GnRH}$ is used, emergence of the new follicular wave is accompanied by formation of the GnRH-induced accessory corpus luteum. Due to the difference in time of emergence between GnRH and estradiol, the progestin is withdrawn and $\mathrm{PGF}_{2 a}$ is given either $7(\mathrm{GnRH})$ or 8 to 9 (estradiol) days later. Hence, progesterone is withdrawn 5 to 6 days after emergence of a dominant follicle. The final step is to synchronize ovulation with either GnRH, given 60-66 hours after $\mathrm{PGF}_{2 \alpha^{\prime}}$ estradiol cypionate which is given at progestin withdrawal, or $17 \mathrm{~B}$-estradiol/EB given 24 to 48 hours after PGF $_{2 \alpha}$.

\section{Estrous synchronization and timed $\mathrm{Al}$ with $\mathrm{CnRH}$}

The standard GnRH-based timed Al program used in the USA is referred to as the "CO-Synch + CIDR" program (Figure 1). Some of the key research that led to development of this program (Macmillan and Thatcher, 1991; Twagiramunga et al., 1995; Pursely et al., 1995; Geary et al., 2001; Lamb et al., 2001) culminated in a large multistate project (Larson et al., 2006) which reported that timed-Al pregnancy rate with the CO-Synch + CIDR program was $54 \%$. This program is a widely used estrous synchronization system for timed Al in beef cows in the USA.

While the CO-Synch + CIDR program has been successful and yielded acceptable timed-AI pregnancy rates, limitations to fertility have been linked to the lack of coordination of follicular development in some females. Failure of the first $\mathrm{GnRH}$ to reset follicular development leads to aberrant follicular dynamics during the synchronization program (Geary et al., 2000) and the induced ovulation of small follicles in some animals by the second GnRH (Perry et al., 2005). Cattle induced to ovulate follicles smaller than observed at a spontaneous estrus with the second GnRH have decreased fertility (Lamb et al., 2001; Perry et al., 2005). The capacity of the first $\mathrm{GnRH}$ to reset follicular development as well as stage of the estrous cycle at treatment has been linked to size of the dominant follicle at the time of the second GnRH (Atkins et al., 2008, 2010). Hence, pregnancy rate to timed Al with the standard CO-Synch + CIDR program is limited by induced ovulation of compromised follicles.

\section{Follicular maturity and fertility in cattle}

The influence of ovulatory follicle maturity on fertility in beef cattle has been investigated (Mussard ef al., 2003; 2007; Bridges et al., 2010; Perry et al., 2005). One hypothesis was that diameter of ovulatory follicles was the most appropriate indicator of follicle "maturity" and that cows induced to ovulate small follicles would have decreased fertility compared to cows which are induced to ovulate large dominant follicles. Within each of three experiments (Table 1; Mussard et al., 2003; 2007) this hypothesis was supported, but as data accumulated,from multiple experiments, the relationship of follicle diameter to pregnancy rate appeared inconsistent, In fact, across experiments, the more consistent predictor of pregnancy rate appeared to be the interval from initiation of luteal regression with PGF $_{2 \alpha}$ to either a spontaneous or GnRH-induced $\mathrm{LH}$ surge (Table 1). Since the stage of a spontaneous estrous cycle between luteal regression and initiation of estrus and the $\mathrm{LH}$ surge is typically referred to as proestrus, we, in turn, refer to the interval from $\mathrm{PGF}_{2 a}$ (and progestin withdrawal when applicable) to GnRH treatment as 'proestrus' in our research. The observed relationship between length of proestrus and conception rate led to an additional experiment (Table 1; Bridges et al., 2010) designed 
to hold follicle diameter constant and only vary length of proestrus. It was demonstrated that at a constant ovulatory follicle diameter, length of proestrus had a substantial influence on conception rate. Taken together, data from this series of studies suggested a strong positive relationship of duration of proestrus with follicle maturity and fertility, and furthermore, suggested that diameter of the ovulatory follicle, in itself, was not a consistent predictor of follicle maturity. The effect of ovulatory follicle size at $\mathrm{GnRH}$-induced ovulation or at spontaneous ovulation on conception rate has also been evaluated by Perry et al. $(2005,2007)$. It was reported that diameter of the ovulatory follicle influenced conception rate after detection of estrus in heifers, but not in postpartum cows. In postpartum cows that did not exhibit estrus, diameter of the ovulatory follicle was positively associated with conception rate when ovulation was induced with GnRH. Thus, if a 'complete' spontaneous proestrus occurred in cows (confirmed by exhibition of estrus), diameter of the ovulatory follicle did not impact fertility. The impact of follicle diameter on conception rate was evident when ovulation was induced with $\mathrm{GnRH}$; at a constant duration of proestrus. Since findings suggested that maturity of the ovulatory follicle and probability of conception is perhaps best defined by length of proestrus, we applied this knowledge towards optimizing the existing CO-Synch + CIDR program to take advantage of this relationship.

Table 1. Conception rate, diameter and age of the ovulatory follicle, duration of proestrus, and number of cows included from a series of experiments investigating the effect of follicle maturity on fertility.

\begin{tabular}{|c|c|c|c|c|}
\hline $\begin{array}{c}\text { Conception rate } \\
(\%)^{\mathrm{a}}\end{array}$ & $\begin{array}{c}\text { Follicle diameter at } \\
\text { ovulation }(\mathrm{mm})^{\mathrm{b}}\end{array}$ & $\begin{array}{c}\text { Duration of proestrus } \\
\text { (days) }\end{array}$ & $\mathrm{n}$ & Experiment \\
\hline 4 & $11.1 \pm 0.2$ & $1.0 \pm 0.1$ & 45 & Mussard et al., 2003a \\
\hline 8 & $11.1 \pm 0.2$ & $1.0 \pm 0.1$ & 12 & Mussard et al., 2003b' \\
\hline 10 & $12.6 \pm 0.2$ & 1.25 & 10 & Bridges et al., $2010^{\mathrm{s}}$ \\
\hline 57 & $13.6 \pm 0.2$ & $2.2 \pm 0.1$ & 54 & Mussard et al., $2003 \mathrm{a}^{e}$ \\
\hline 67 & $13.7 \pm 0.2$ & $2.0 \pm 0.1$ & 12 & Mussard et al., 2003b \\
\hline 71 & $12.9 \pm 0.2$ & 2.25 & 28 & Bridges et al., $2010^{5}$ \\
\hline 76 & $10.7 \pm 0.1$ & $3.3 \pm 0.1$ & 29 & Mussard et al., 2007 \\
\hline 100 & $12.0 \pm 0.3$ & $4.7 \pm 0.2$ & 24 & Mussard et al., 2007 \\
\hline
\end{tabular}

a Percentage of animals determined to be pregnant following insemination. Pregnancy determination was conducted via ultrasonography at approximately 30 days post-insemination.

${ }^{b}$ Diameter of the largest ovulatory follicle as determined by ultrasonography conducted either at GnRH administrátion or estrus.

Interval from PGF until GnRH administration.

${ }^{d}$ Cows were either induced with $\mathrm{GnRH}$ to ovulate a small $(-11 \mathrm{~mm})$ follicle or allowed to spontaneously exhibit estrus. Cows were inseminated 12 hours following estrus or $\mathrm{GnRH}$.

"Cows were induced to ovulate either a small $(\sim 11 \mathrm{~mm})$ or large $(\sim 13 \mathrm{~mm})$ ovarian follicle with GnRH. Animals were inseminated $12 \mathrm{~h}$ following $\mathrm{GnRH}$ administration.

${ }^{\prime}$ Cows were induced to ovulate either a small $(\sim 11 \mathrm{~mm})$ or large $(\sim 13 \mathrm{~mm})$ ovarian follicle with GnRH. Embryo from non-treated cows were then transferred 7 days after $\mathrm{GnRH}$.

"Cows were induced to ovulate an ovarian follicle of similar diameter with GnRH either 1.25 or 2.25 days following $\mathrm{PGF}_{2 \mathrm{a}}$ administration. Animals were inseminated $12 \mathrm{~h}$ following $\mathrm{GnRH}$ administration. Includes only cows with a luteal phase of normal length.

\section{Lengthening proestrus in the CO-Synch + CIDR program}

The length of proestrus (interval from $\mathrm{PGF}_{2 a}$ to second $\mathrm{GnRH}$ and timed AI) with the traditional 7-day CO-Synch + CIDR program was varied from 56 to 72 hours in mature cows without 
influencing timed $\mathrm{AI}$ pregnancy rate, but in younger cows ( $\leq 3$ years of age), greatest pregnancy rates were achieved with timed $\mathrm{Al}$ at 56 hours (Dobbins et al., 2009). Others (Busch et al., 2008) have reported that timed $\mathrm{Al}$ pregnancy rates were greater when proestrus was 66 than 54 hours. In practice, the second $\mathrm{GnRH}$ is given and timed Al is performed in most herds between 54 and 66 hours after $\mathrm{PGF}_{2 \alpha^{3}}$ and there is no evidence that extending this interval beyond 66 hours will increase timed $\mathrm{AI}$ pregnancy rate. It was theorized that if the interval from the first $\mathrm{GnRH}$

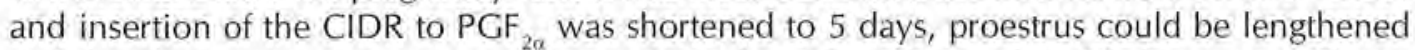
and timed-AI pregnancy rate would increase. In the 5-day CO-Synch + CIDR program (Figure 1), two rather than one injection of PGF $_{2 \alpha}$ are administered at CIDR withdrawal, which is 5 days after CIDR insertion and the first GnRH injection. With this approach, the new follicular wave emerges 3 to 4 days before $\mathrm{PGF}_{22}$ is given, which is earlier relative to emergence of the ovulatory follicle ( 5 to 6 days) in the 7-day CO-Synch + CIDR program. Thus, the dominant follicle enters proestrus at a follicular age when follicular fluid concentrations and capacity of granulosa cells to produce estradiol are greater than with the 7 day program (Valdez et al., 2005). Bridges et al. (2008) determined that the appropriate interval from $\mathrm{PGF}_{20}$ to the second $\mathrm{GnRH}$ and timed-AI with the 5 day program was 72 hours. In comparison with the traditional 7 day CO-Synch + CIDR program, the 5-day CO-Synch + CIDR program increased timed-AI pregnancy rate from 59.9 to $70.4 \%$ (Bridges et al., 2008). Similarly, a $14 \%$ increase in timed-Al pregnancy rate was detected in yearling heifers with the 5-day as compared to 7-day program (Wilson et al., 2007). This substantial increase in timed-Al pregnancy rate with the 5-day program has been achieved using two doses of PGF hours apart. Pregnancy rate is decreased with a single dose of PGF Pr $_{2 \alpha}$ or CLP (Kasimanickam., et al. 2009; Souto et al., 2009) due to failure of a single dose to induce luteal regression in approximately $1 / 3$ of cows (Souto et al., 2009). Cruppe et al. (2010) recently reported that giving two simultaneous doses of PGF together at the time of CIDR withdrawal in the 5-day program resulted in pregnancy rates similar to those achieved with two injections, spaced 8 hours apart. Collectively, experiments that have included over 1700 cows across 23 herds and four years, have achieved a mean pregnancy rate of $68.4 \%$ with the 5 -day CO-Synch + CIDR program using two doses of PGF $_{2 a}$ given simultaneously or spaced $2,7,8$ or 12 hours apart, depending upon individual experimental objectives.

\section{Hormonal impact of lengthened proestrus}

Proestrus starts with the diappearance of progesterone and terminates with either a spontaneous or $\mathrm{GnRH}$ - induced $\mathrm{LH}$ surge. An immediate response to declining progesterone is an increase in the frequency of LH pulses (Kinder et al., 1996), providing the primary stimulus for final development of preovulatory follicles (Ireland and Roche, 1983) and the preovulatory increase in estradiol (Kaneko et al., 1991). Concentrations of estradiol, magnitude of the $\mathrm{LH}$ surge, and progesterone concentrations during the ensuing luteal phase were compared in cattle experiencing either a short (SPE) or long (LPE) proestrus (Figure 2; Bridges et al., 2010). Ovulatory follicle size was similar and the magnitude of the GnRH-induced LH surge did not differ between treatments. There tended to be lower concentrations of progesterone in the SPE treatment, however, the most striking difference was the greater concentrations of estradiol in the LPE treatment during the 32 hours preceding GnRH administration (Figure 3). In another model, when proestrus was lengthened in the 5-vs. the 7-day CO-Synch + CIDR program, diameter of the ovulatory follicle did not differ but peak estradiol concentration tended to be greater with the 5-day program (Bridges et al., 2009). It has been concluded that increasing the length of proestrus escalates preovulatory concentrations of estradiol, presumably through 
prolonged gonadotropic stimulation of the dominant follicle, resulting in increased timed-Al pregnancy rates in the 5-day CO-Sync + CIDR program.

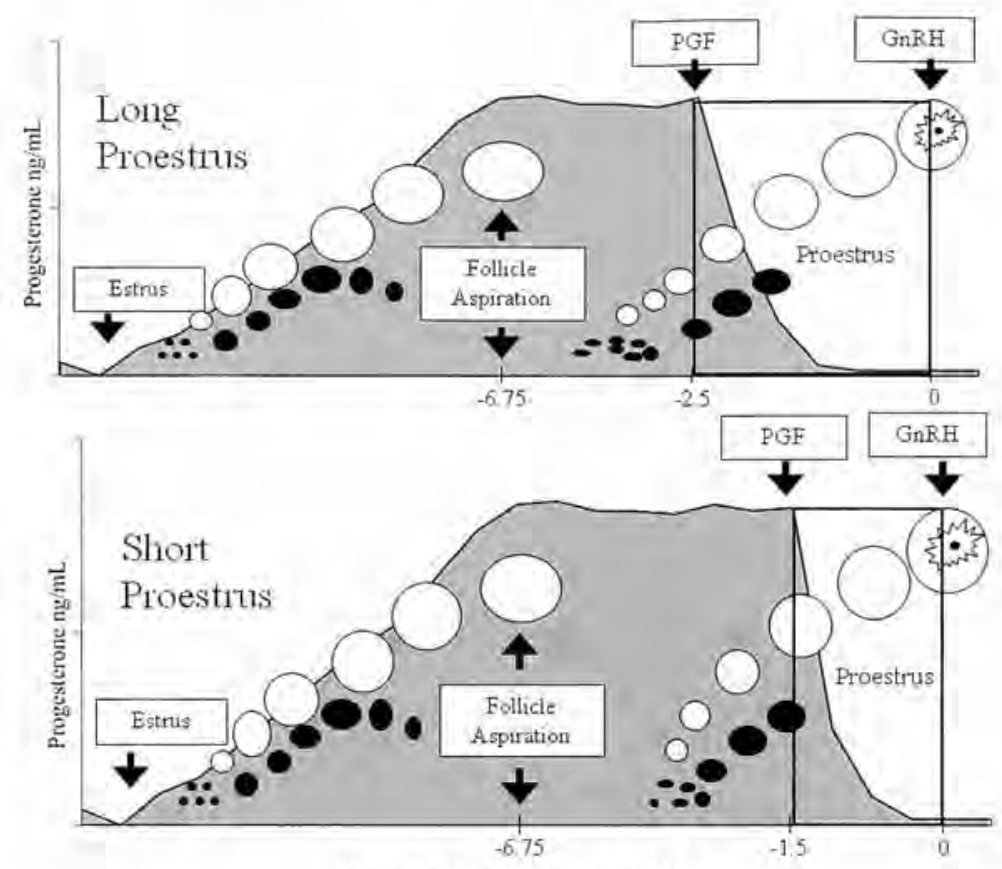

Days Relative to GmRH

Fig. 2. Animal model used in a series of experiments cited to result in treatments that varied in length of proestrus and prevovulatory estradiol concentrations. Animals were synchronized to a common day of estrus prior to ovarian follicular aspiration. Ovarian follicular aspiration resulted in emergence of a new wave of follicles either 1 or 2 days after aspiration. In the Long Proestrus treatment, PGF $_{2 a}$ (PGF) was administered approximately 4 days after aspiration and $\mathrm{GnRH}$ given 2.5 days later. In the Short Proestrus treatment, PGF was given 5 days after emergence and GnRH administered 1.5 days later.

Increased gonadotropic stimulus in estradiol-based synchronization programs

Scientists that work with estradiol-based programs (Figure 1) in Bos indicus influenced cattle have investigated alternative approaches to enhance gonadotropic stimulation of the dominant follicle during synchronization. The capacity of progesterone to regulate frequency of LH pulses occurs along a continuum of concentrations. If concentrations of progesterone are reduced but not to basal levels, a measurable increase in $\mathrm{LH}$ pulse frequency that is capable of stimulating growth of the dominant follicle occurs (Kinder et al., 1996). Therefore, it is conceivable that if progesterone concentrations are less during the period of progestin treatment during estrous synchronization, maturity of the dominant follicle at initiation of proestrus would be advanced and thereby result in increased estradiol concentrations and fertility.

One approach is to induce luteal regression before the end of progestin treatment using PGF $2 a$ in order to remove contributions to peripheral progesterone concentrations from the corpus luteum, leaving the exogenous treatment as the only progestin source. When $\mathrm{PGF}_{2 \alpha}$ was given on the fourth day of an 8-day estradiol based program, pregnancy rate to embryo transfer was enhanced (Moreno et al., 2002). In cyclic cows that received $\mathrm{PGF}_{20}$ on either day 7 or day 9 


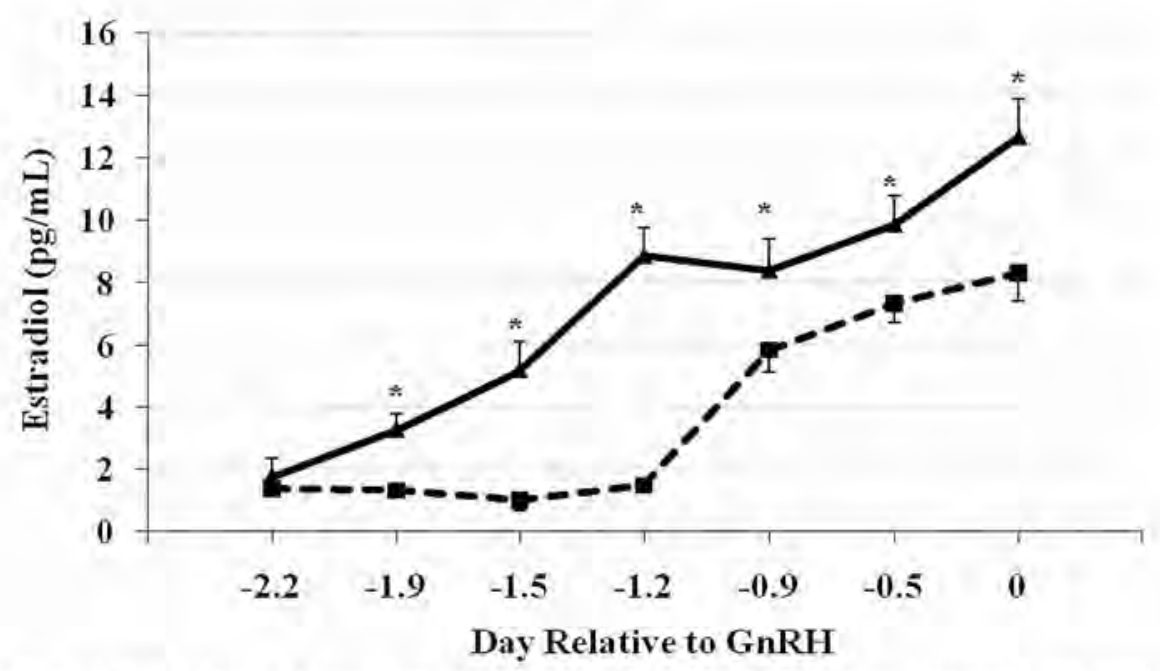

Fig. 3. Preovulatory plasma estradiol concentrations of beef cows that were induced to ovulate a similar sized follicle following either a long (2.2 days; LPE; $\mathbf{A}$ ) or short (1,2 days; SPE $; \square$ proestrus. Asterisks indicate times that differed $(P<0.05)$ between treatments.

of a 9-day estradiol-based synchronization program (Peres et al., 2009), treatment with PGF ${ }_{2 \alpha}$ on day 7 reduced progesterone concentrations on day 9 (just before progestin withdrawal) and increased diameter of the ovulatory follicle and timed-AI pregnancy rate. Alternatively, a device that releases less progesterone, such as a CIDR that has been used previously to synchronize estrus (Martinez et al., 2003), could be inserted to lessen progesterone concentrations during treatment. Diameter of the ovulatory follicle and timed AI pregnancy rate were greater in Nelore heifers that received a twice-used CIDR compared to a new CIDR (Dias et al., 2009). While neither of these approaches technically increases the length of proestrus, the reduction in progesterone concentrations before the onset of proestrus increased follicular diameter, suggesting that the endpoint of increasing maturity of the dominant follicle and timed Al pregnancy rate may have been achieved.

Rather than using the approaches designed to increase endogenous LH listed above, administration of exogenous gonadotropins has also been used enhance follicular maturity. Treatment of beef cows with eCG on the fifth day of an 8-day estradiol based program (Tribulo et al., 2002) increased pregnancy rate of embryo transfer recipients. Likewise, treatment with exogenous eCG at the start of proestrus increased diameter of the ovulatory follicle and timed-Al pregnancy rate in estradiolbased programs (Baruselli et al., 2004; Peres et al., 2009; Dias et al., 2009). With this approach the gonadotropic stimulus is provided exogenously, but a similar net outcome of enhanced follicular growth and fertility is achieved.

\section{Impact of length of proestrus on embryonic mortality}

The animal model described in Figure 2 has been used to investigate the impact of length of proestrus and associated changes in preovulatory estradiol concentrations on uterine function and embryo development in cattle (Bridges et al., 2005; 2006a; 2006b; 2010). Due to the impact on estradiol concentrations, hereafter LoE refers to the SPE treatment and HiE refers the LPE treatment. In the first experiment gene expression for oxytocin receptor and cyclooxygenase- 2 in the uterus on day 5 of the estrous cycle were greater in LoE than HiE treatment (Bridges et a., 2005) indicating that treatments influence expression of genes known to regulate luteal function. The objective of the second experiment was to determine the effect of decreased preovulatory estradiol concentrations 
on embryonic development to day 6 of pregnancy (Bridges et al., 2006a). Embryos were collected on day 6 of gestation from cows that were $\mathrm{Al}$ following the HiE and LoE treatments. Fertilization rate, embryo grade, total cells per embryo, and accessory sperm cell number were similar between treatments. Although the number of recovered embryos was somewhat limiting, findings indicated that catastrophic defects in early embryo development were not associated with the LoE treatment. In a third experiment, aspects of conceptus and uterine function were compared on day 15.5 of gestation between cows that received the $\mathrm{HiE}$ and $\mathrm{LoE}$ treatments and were implanted with embryos from untreated cattle on d 15.5 of gestation (Bridges et al., 2006b, Bridges and Day, unpublished). Content of IFN- $\tau$ in the uterine lumen and uterine concentrations of $M R N A$ for ISG-15 and MX-1 from pregnant animals did not differ between treatments. Nuclear progesterone receptors, predominantly localized in the deep glandular epithelium were more abundant $(P<0.05$; Figure 4$)$ in the HiE than LoE treatment. Results of this experiment suggest that up to day 15.5 of pregnancy, decreased preovulatory estradiol concentrations do not impair conceptus development or its ability to induce mRNA for interferon stimulated genes in the uterus. However, alterations in uterine progesterone receptors existed at this stage of pregnancy. Previous research (Table 1) has demonstrated a substantial negative impact of shortened proestrus on pregnancy rate by day 30 after ovulation (either with $\mathrm{Al}$ or embryo transfer) and in Experiment 2 (Mussard et al., unpublished) return to estrus following Al for non-pregnant cows with a shortened proestrus was approximately 25 days, suggesting that embryos survived through maternal recognition of pregnancy in some females but were lost shortly thereafter. It is therefore proposed that pregnancy loss in animals that have suboptimal preovulatory estradiol concentrations occurs after maternal recognition of pregnancy during the pre-implantation period but before day 30 of gestation. The hypothesis of ongoing experiments is that decreased preovulatory estradiol concentrations lead to inappropriate gene expression and protein synthesis by the uterus, which results in the inability of the uterus to sustain the conceptus through the preimplantation period.

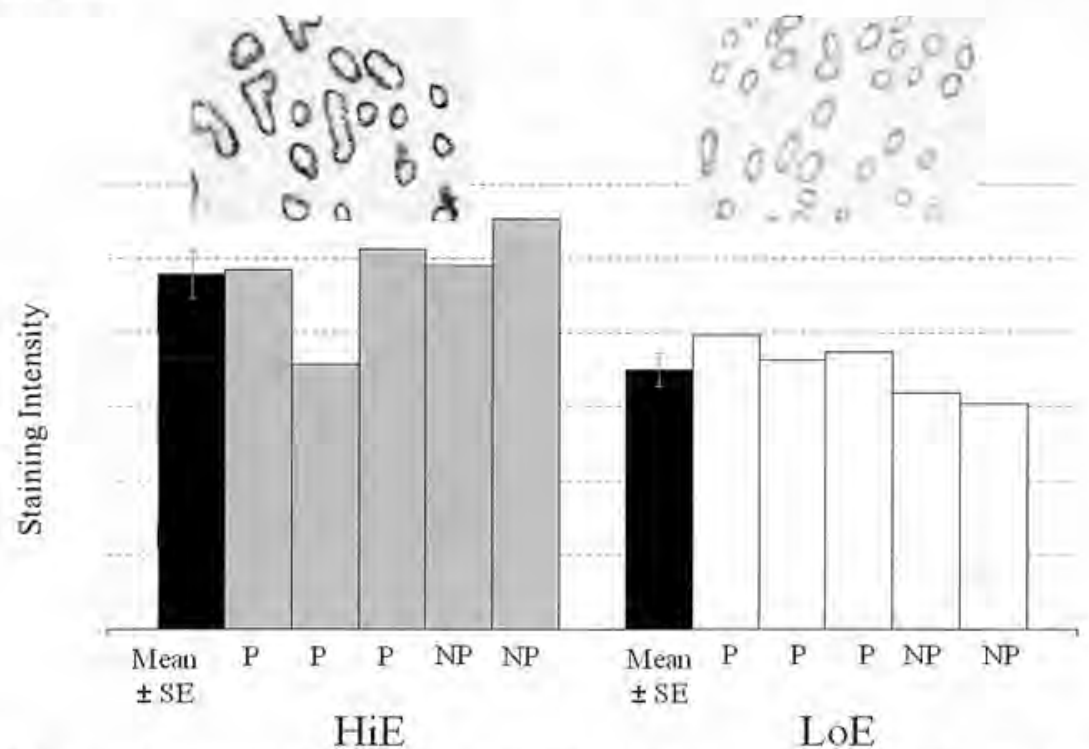

Fig. 4. Nuclear progesterone receptor in the deep uterine glandular epithelium in cattle on day 15.5 of the estrous cycle in pregnant (P) and nonpregnant (NP) heifers that were induced to ovulate a similar sized follicle following either a long proestrus ( 2.5 days) that increased preovulatory estradiol concentrations ( $\mathrm{HiE}$ ) or a shortened proestrus (1.5 days) that resulted in reduced preovulatory concentrations (LoE). Representative sections from females in each treatment are shown above the respective treatment. Staining intensity differed between treatment, $\mathrm{P}<0.05$. 


\section{Conclusions}

Significant discoveries in the past two decades in reproductive biology regarding the manner in which ovarian follicles grow, the impact of exogenous intervention on this growth and description of methods to coordinate this process have led to development of estrous synchronization programs that consistently result in timed-Al pregnancy rates of $50 \%$ or greater in beef cattle. Recent advancements have pushed this proportion to almost $70 \%$ with some programs and emphasize that adequate gonadotropic stimulation of follicular function before ovulation is requisite to optimize fertility. The mechanisms responsible for variation in fertility related to follicular maturity may include influences on oocyte quality, embryonic growth, oviductal function, luteal function or uterine environment, and a combination of some or all of these critical aspects of pregnancy establishment is likely. The findings suggest that the elevated estradiol concentrations that result from increased stimulation of the dominant follicle may be responsible for increased fertility through actions to create a uterine environment capable of sustaining the embryo through to attachment.

\section{Acknowledgements}

This project was supported by National Research Initiative Competifive Grants no. 2007-3520318118 from the USDA National Institute of Food and Agriculture and no. 00-35203-9133 and 94-37203-0923 from the USDA Cooperative State Research, Education, and Extension Service; Select Sires, Plain City, $\mathrm{OH}$; COBA/Select Sires, Columbus, $\mathrm{OH}_{\text {; }}$ Pfizer Animal Health (New York, NY); and Teva Animal Heath (St Joseph, MO). Salaries and research support provided by State and Federal funds appropriated to the Ohio Agricultural Resource Development Center (OARDC; Manuscript No. 15/10/AS). Appreciation is expressed to graduate students and research personnel that contributed to the project; Les Anderson, Chad McDowell, Valerie Bogacz, Chad Gasser, Lucas Helser, Martin Maquivar, Lucas Souto, Leandro Cruppe, Fernanda Abreu and David Grum.

\section{References}

Ahmad N, Schrick FN, Butcher RL \& Inskeep EK 1995 Effect of persistent follicles on early embryonic losses in beef cows. Biology of Reproduction 52 1129-1135.

Anderson LH \& Day ML 1994 Acute progesterone administration regresses persistent dominant follicles and improves fertility of cattle in which estrus was synchronized with melengestrol acetate. Journal of Animal Science 72 2955-2961.

Anderson LH \& Day ML 1998 Development of a progestin-based estrus synchronization program: I. Reproductive response of cows fed melengestrol acetale for 20 days with an injection of progesterone. Journal of Animal Science 76 1267-1272.

Atkins JA, Busch DC, Bader JF, Keisler DH, Patterson DJ, Lucy MC \& Smith MF 2008 Gonadotropin-releasing hormone-induced ovulation and luteinizing hormone release in beef heifers: effect of day of the cycle. Journal of Animal Science 86 83-93.

Atkins JA, Smith MF, Wells KJ \& Geary TW 2010 Factors affecting pre-ovulatory follicle diameter and ovulation rate to $\mathrm{GnRH}$ in postpartum beef cows Part I: Cycling cows. Journal of Animal Science doi:10.2527/j as 2009-2531.

Baruselli PS, Reis EL, Marques MO, Nasser LF \& Bó GA 2004 The use of hormonal treatments to improve reproductive performance of anestrous beef cattle in tropical climates. Animal Reproduction Science 82-83 479-486.

Beal WE, Chenault JR, Day ML \& Corah LR 1988 Variation in conception rates following synchronization of estrus with melengestrol acetate and prostaglandin $F 2 \alpha$. Journal of Animal Science 66 599-602.

Bo GA, Adams GP, Pierson RA \& Mapletoft RJ 1995 Exogenous control of follicular wave emergence in cattle. Theriogenology 43 31-40.

Bridges GA, Mussard ML, Winkler JL, Gasser CL, Grum DE, Pate JL \& Day ML 2005 Influence of duration of proestrus on preovulatory estradiol concentrations and uterine gene expression following induced ovulation in cattle. Proceedings of the 38th Society for the Study of Reproduction Annual Meetings M451 (abstract).

Bridges GA, Mussard ML, Grum DE, Helser LA, Gasser 
CL, Dauch DM, Pate IL \& Day ML 2006a The influence of pre-ovulatory estradiol concentrations on uterine function in beef cattle. lournal of Animal Science $\mathbf{8 4}$ (Supplement 2) 101 (abstract).

Bridges GA, Mussard ML, Helser LA, Grum DE, Lantz DM, Ott TL, Pate IL \& Day ML 2006b Effect of preovulatory estradiol concentrations on conceptus and uterine development. Proceedings of the 7 th International Ruminant Reproduction Symposium. 90 (abstract).

Bridges GA, Helser LA, Grum DE, Mussard ML, Gasser CL \& Day ML 2008 Decreasing the interval between GnRH and PGF $2 \alpha$ from 7 to 5 days and lengthening proestrus increases timed-Al pregnancy rates in beef cows. Theriogenology 69 843-851.

Bridges GA, Mussard ML, Helser LA \& Day ML 2009 Comparison of follicular dynamics and hormone concentrations between the $7 \mathrm{~d}$ and $5 \mathrm{~d}$ CO-Synch + CIDR program in two-year old beef cows, Joumal of Animal Science $\mathbf{8 7}$ (Supplement 2) 372 (abstract).

Bridges GA, Mussard ML, Burke CR \& Day ML 2010 Influence of the length of proestrus on fertility and endocrine function in female cattle. Animal Reproduction Science 117 208-215.

Brown LN, Odde KG, LeFever DG, King ME \& Neubauer C] 1988 Comparison of MGA-PGF $2 \alpha$ to SyncroMate $\mathrm{B}$ for estrous synchronization in beef heifers. Theriogenology 30 1-12.

Busch DC, Schafer DI, Wilson DJ, Mallory DA, Leitman NR, Haden IK, Ellersieck MR, Smith MF \& Patterson DJ 2008 Timing of artificial insemination in postpartum beef cows following administration of the CO-Synch + controlled internal drug-release protocol. Journal of Animal Science $861519-25$.

Burke CR, Morgan S, Clark BA \& Rhodes FM 1998 Effect of luteolysis on control of ovarian follicles using oestradiol benzoate and progesterone in cattle. Proceedings of the New Zealand Society of Animal Production 58 89-91.

Burke CR, Day ML, Bunt CR \& Macmillan KL 2000 Use of a small dose of estradiol benzoate during diestrus to synchronize development of the ovulatory follicle in cattle. Journal of Animal Science 78 145-151.

Burke CR, Mussard ML, Grum DE \& Day ML 2001 Effects of maturity of the potential ovulatory follicle on the provocation of oestrus and ovulation in cattle with oestradiol benzoate. Animal Reproduction Science 66 161-174.

Burke CR, Mussard ML, Gasser CL, Grum DE \& Day ML 2003. Estradiol benzoate delays new follicular wave emergence in a dose dependent manner after ablation of the dominant ovarian follicle in cattle. Theriogenology $\mathbf{6 0}$ 647-658.

Burke CR, Cardenas H, Mussard ML \& Day ML 2005 Histological and steroidogenic changes in dominant ovarian follicles during oestradiol-induced atresia in heifers. Reproduction $129611-620$.

Burke CR, Cardenas H, Mussard ML, Gasser CL \& Day ML 2007. Steroidogenic changes and expression of messenger RNA encoding steroidogenic enzymes, gonadotrophin receptors and cell-death signaling in the dominant ovarian follicle during oestradiolinduced atresia in cattle. Animal Reproduction Science 99 244-257.

Christian RE \& Casida LE 1948 The effect of progesterone in altering the estrual cycle of the cow. Journal of Animal Science 7540 (abstract).

Cruppe LH, Souto LA, Maquivar M, Gunn P, Mussard ML, Wolfenson D, Pires AV, Bridges GA \& Day ML 2010 Use of two coincident doses of PGF $2 \alpha$ with the 5-d CO-Synch + CIDR estrous synchronization program. In ADSA-PSA-AMPA-CSAS-WSASAS-ASAS Joint Annual Meeting, July 11-15, Denver, Colorado, USA

Day ML 2004 Hormonal induction of estrous cycles in anestrous, Bos taurus beef cows. Animal Reproduction Science 82-83 487-494.

Day ML \& Burke CR 2002 Management of follicular growth with progesterone and estradiol within progestin - based estrous synchrony systems. In Factors Affecting Calf Crop, Biotechnology of Reproduction, p. 101 Eds Fields MJ, Sand RS \& Yelich JV. New York, NY:CRC Press.

Day ML, Burke CR, Taufa VK, Day AM \& Macmillan KL 2000. The strategic use of estradiol to enhance fertility and submission rates of progestin based estrus synchronization programs in seasonal dairy herds. Journal of Animal Science 78 523-529.

Dias CC, Wechsler FS, Day ML \& Vasconcelos JLM 2009 Progesterone concentrations, exogenous eCG and timing of prostaglandin $F 2 \alpha$ treatment affect fertility in postpubertal Nelore heifers. Theriogenology 72 $378-385$.

Dobbins CA, Eborn DR, Tenhouse DE, Breiner RM, Johnson SK, Marston TT \&. Stevenson IS 2009 Insemination timing affects pregnancy rates in beef cows treated with CO-Synch protocol including an intravaginal progesterone insert. Theriogenology 72 1009-1016.

Engelhardt H, Walton JS, Miller RB \& King GJ 1989 Estradiol-induced blockade of ovulation in the cow: Effects of luteinizing hormone release and follicular fluid steroids. Biology of Reproduction 40 1287-1297.

Geary TW, Downing ER, Bruemmer JE \& Whittier IC 2000 Ovarian and estrous response of suckled beef cows to the select synch estrous synchronization protocol. The Professional Animal Scientist 16 1-5.

Geary TW, Salverson RR \& Whittier IC 2001 Synchronization of ovulation using GnRH or hCG with the CO-Synch protocol in suckled beef cows. Journal of Animal Science 79 2536-2541.

Ginther O I, Knopf L \& Kastelic JP 1989 Temporal associations among ovarian events in cattle during oestrous cycles with two and three follicular waves. Journal of Reproduction and Fertility 87 223-230.

Ireland JJ \& Roche JF 1983 Growth and differentiation of large antral follicles after spontaneous luteolysis in heifers: Changes in concentration of hormones in follicular fluid and specific binding of gonadotropins to follicles. Journal of Animal Science 57 157-167.

Kaltenbach CC, Dunn TG, Kiser TE, Corah LR, Akbar AM 
\& Niswender GD 1974 Release of FSH and LH in beef heifers by synthetic gonadotropin releasing hormone. Journal of Animal Science 38 357-362.

Kaneko H, Terada I, Taya K, Watanabe G, Sasamoto S, Hasegawa Y \& Igarashi M 1991 Ovarian follicular dynamics and concentrations of oestradiol-17ß, progesterone, luteinizing hormone and follicle stimulating hormone during the periovulatory phase. of the oestrous cycle in the cow. Reproduction Fertility \& Development 3 529-535.

Kasimanickam R, Day ML, Rudolph JS, Hall JB \& Whittier WD 2009 Two doses of prostaglandin improve pregnancy rates to timed-Al in a 5-day progesterone-based synchronization protocol in beef cows. Theriogenology 71 762-767.

Kinder JE, Kojima FN, Bergfeld EGM, Wehrman ME \& Fike KE 1996 Progestin and estrogen regulation of pulsatile $\mathrm{LH}$ release and development of persistent ovarian follicles in cattle. Journal of Animal Science 74 1424-1440.

King ME, Kiracofe GH, Stevenson JS \& Schalles RR 1982 Effect of stage of the estrous cycle on interval to estrus after PGF $2 \alpha$ in beef cattle. Theriogenology 18 191-200.

Lamb GC, Nix DW, Stevenson IS \& Corah LR 2000. Prolonging the MGA-Prostaglandin F2 $\alpha$ interval from 17 to 19 days in an estrus synchronization system for heifers. Theriogenology 53 691-698.

Lamb GC, Stevenson JS, Kesler DJ, Garverick HA, Broan DR \& Salfen BE 2001 Inclusion of an intravaginal progesterone insert plus GnRH and prostaglandin F2a for ovulation control in postpartum suckled beef cows. Journal of Animal Science 79 2253-2259.

Larson JE, Lamb GC, Stevenson JS, Johnson SK, Day ML, Geary TW, Kesler DJ, DeJarnette JM, Schrick FN, DiCostanzo A \& Arseneau JD 2006 Synchronization of estrus in suckled beef cows before detected estrus and (or) timed artificial insemination using gonadotropinreleasing hormone (GnRH), prostaglandin F2 $\alpha$ (PG), and progesterone (CIDR). Journal of Animal 5cience $84332-342$.

Lauderdale JW 1975 The use of prostaglandin in cattle. Annales de Biologie Animale Biochimie Biophysique 15 419-425.

Lemon M, Pelletier I, Saumande J \& Signoref JP 1975 Peripheral plasma concentrations of progesterone, oestradio- $17 ß$ and luteinizing hormone around oestrus in the cow. Journal of Reproduction and Fertility $\mathbf{4 2}$ 137-140.

Macmillan KL \& Thatcher WW 1991 Effects of an agonist of gonadotropin-releasing hormone on ovarian follicles in cattle, Biology of Reproduction 45 883-889.

Mallory DA, Wilson DJ,Busch DC, Ellersieck MR, Smith MF \& Patterson DJ 2010 Comparison of long-term progestin-based estrus synchronization protocols in beef heifers /ournal of Animal Science doi: 10.2527jas.2010-3084.

Martinez MF, Colazo MG, Kastelic JP \& Mapletoft RJ 2003 a Effects of estradiol and progesterone on plasma steroid and gonadotropin concentrations in
CIDR-treated ovariectomized cows. Theriogenology 59224 (abstract).

Mauleon P 1974 New trends in the control of reproduction in the bovine. Livestock Production Science 1117. 1.31.

McCracken JA, Carlson JC, Glew ME, Goding JR, Baird DT, Green K \& Samuelsson B 1972 Prostaglandin F2a identified as a luteolytic hormone in sheep. Nature New Biology 238 129-134.

McDowell CM, Anderson LH, Kinder JE \& Day ML 1998a Duration of treatment with progesterone and regression of persistent ovarian follicles in cattle. lournal of Animal Science 76 850-855.

McDowell CM, Anderson LH, Lemenager RP, Mangione DA \& Day ML 1998b Development of a progestinbased estrus synchronization program: II. Reproductive response of cows fed melengestrol acetate for 14 days with injections of progesterone and prostaglandin F2a. Journal of Animal Science 76 1273-1279.

Meneghetti M, Sa Filho OG, Peres RFG, Lamb GC \& Vasconcelos JLM 2009 Fixed-time artificial insemination with estradiol and progesterone for Bos indicus cattle: I. Basis for development of protocols. Theriogenology 72 179-189.

Mihm M, Baguisi A, Boland MP \& Roche JF 1994 Association between the duration of dominance of the ovulatory follicle and pregnancy rate in beef heifers. Journal of Reproduction and Fertility 102 123-130.

Miksch ED, LeFever DG, Mukembo G, Spitzer JC \& Wiltbank JN 1978. Synchronization of estrus in beef cattle. II. Effect of an injection of norgestomet and an estrogen in conjunction with a norgestomet implant in heifers and cows. Theriogenology $\mathbf{1 0}$ 201-221.

Moreira F, de la Sota RL, Diaz T \& Thatcher WW 2000 Effect of day of the estrous cycle at the initiation of a timed artificial insemination prolocol on reproductive responses in dairy heifers. Journal of Animal Science 78 1568-1576.

Moreno D, Cutaia L, Tribulo $H$, Tribulo R, Villata ML, Caccia M \& Bo G 2002 Effect of time of prostaglandin administration on pregnancy rates in embryo recipients treated with progesterone vaginal devices and transferred without estrus detection. Theriogenology 57552 (abstract).

Mussard ML, Burke CR \& Day ML 2003 Ovarian follicle maturity at induced ovulation influences fertility in cattle. Proceedings of the Annual Conference of the Society for Theriogenology 79-185.

Mussard ML, Burke CR, Behlke EJ, Gasser CL \& Day ML 2007 Influence of premature induction of an LH surge with $\mathrm{GnRH}$ on ovulation, luteal function and fertility in cattle. Journal of Animal Science 85 937-943.

Odde KG 1990 A review of synchronization of estrus in postpartum cattle. Journal of Animal Science 68 817-830.

Peres RFG, Claro Junior I, Sa * Filho OG, Nogueira GP \&Vasconcelos ILM 2009 Strategies to improve fertility in Bos indicus postpubertal heifers and nonlactating cows submitted to fixed-time artificial insemination. Theriogenology 72 681-689. 
Perry GA, Smith MF, Lucy MC, Green JA, Parks TE, MacNeil MD, Roberts AJ, \& Geary TW 2005. Relationship between follicle size at insemination and pregnancy success. Proceedings of the National Academy of Science USA 5268-5273.

Perry GA, Smith MF, Roberts AJ, MacNeil MD \& Geary TW 2007. Relationship between size of the ovulatory follicle and pregnancy success in beef heifers. Proceedings of the National Academy of Science USA 5268-5273.

Pursley JR, Mee MO \& Wiltbank MC 1995. Synchronization of ovulation in dairy cows using PGF $2 \alpha$ and $\mathrm{GnRH}$. Theriogenology 44 915-923.

Rajakoski E 1960 The ovarian follicular system in sexually mature heifers with special reference to seasonal, cyclical, and left-right variations. Acta Endocrinologica 34 (Supplement 52) 1-68.

Sa' Filho OG, Meneghetti M, Peres RFG, Lamb GC \& Vasconcelos JLM 2009 Fixed-time artificial insemination with estradiol and progesterone for Bos indicus cattle: II. Strategies and factors affecting fertility. Theriogenology $72210-218$.

Savio JD, Keenan L \& Boland MP 1988 Pattern of growth of dominant follicles during the oestrous cycle of heifers. Journal of Reproduction and Fertility $\mathbf{8 3}$ 663-671.

Savio JD, Thatcher WW, Morris GR, Entwistle K, Drost M \& Mattiacci MR 1993 Effects of induction of low plasma progesterone concentrations with a progesterone-releasing device on follicular turnover and fertility in cattle, Journal of Reproduction and Fertility $9877-84$.

Sirois J \& Fortune JE 1988 Ovarian follicular dynamics during the estrous cycle in heifers monitored by real-time ultrasonography. Biology of Reproduction 39 308-317.

Sirois J \& Fortune JE 1990 Lengthening the bovine estrous cycle with low levels of exogenous progesterone: a model for studying ovarian follicular dominance. Endocrinology 127 916-925.

Souto LA, Maquivar M, Mussard ML, Bridges GA, Grum DE \& Day ML 2009 Fertility and luteal regression with 5-d CIDR synchronization programs in postpartum beef cows using differing luteolytic treatments. Journal of Animal Science 87 (Supplement 2) 372 (abstract).

Stock AE, Fortune JE 1993 Ovarian follicular dominance in cattle: relationship between prolonged growth of the ovulatory follicle and endocrine parameters. Endocrinology 132 1108-1114.

Thatcher WW, Macmillan KL, Hansen PJ \& Drost M 1989 Concepts for regulation of corpus luteum function by the conceptus and ovarian follicles to improve fertility. Theriogenology 31 149-164.

Thimonier J, Chupin D \& Pelot J 1975 Synchronization of oestrus in heifers and cyclic cows with progestagens and prostaglandin analogues alone or in combination. Annales de Biologie Animale Biochimie Biophysique 15 437-449.

Tribulo H, Moreno D, Cutaia L, Gatti G, Tribulo R, Caccia M \& Bo GA 2002 Pregnancy rates in embryo recipients treated with progesterone vaginal devices, and eCG and transferred without estrus detection. Theriogenology 57563 (abstract).

Trimberger GW \& Hansel W 1955 Conception rate and ovarian function following estrus control by progesterone injections in dairy cattle. Journal of Animal Science 14 224-232.

Twagiramungu H, Guilbault LA, Proulx JG \& Dufour JJ 1994 Influence of corpus luteum and induced ovulation on ovarian follicular dynamics in postpartum cyclic cows treated with buserelin and cloprostenol. Journal of Animal Science 72 1796-1805.

Twagiramungu H, Guilbault LA \& Dufour J 1995 Synchronization of Ovarian Follicular Waves with a Gonadotropin-Releasing Hormone Agonist to Increase the Precision of Estrus in Cattle: A Review. Journal of Animal Science 73 3141-3151.

Valdez KE, Cuneo SP, Gorden PJ \& Turzillo AM 2005 The role of thecal androgen production in the regulation of estradiol biosynthesis by dominant bovine follicles during the first follicular wave. Journal of Animal Science 83 597-603.

Wiltbank JN \& Kasson CW 1968 Synchronization of estrus in cattle with an oral progestational agent and an injection of an oestrogen. Journal of Animal Science $27113-116$.

Wilson KN, Day ML, Whittier WD, Kasimanickam R \& Hall JB 2007 Comparison of 5-day or 7-day CIDRbased estrous synchronization systems for fixed-time $\mathrm{Al}$ in beef heifers. Journal of Animal Science $\mathbf{8 5}$ (Supplement 2) 43 (abstract).

Wishart DF 1974 Synchronization of oestrus in cattle using a progestogen (SC21009) and PGF2 $\alpha$. Theriogenology $187-90$.

Wishart DF 1977 Synchronization of oestrus in heifers using steriod (SC 5914, SC 9880 and SC 21009) treatment for 21 days: The effect of treatment on the ovum collection and fertilization rate and the development of the early embryo. Theriogenology $8249-269$.

Zimbelman RG, Smith LW 1966 Control of ovulation in cattle with melengestrol acetate. II. Effects on follicular size and activity, Iournal of Reproduction and Fertility 11 193-201.

Zimbelman RG, Lauderdale JW, Sokolowski JH, Schalk TG 1970 Safety and pharmacologic evaluations of melengestrol acetate in cattle and other animals: A review, lournal of the American Veterinary Medical Association 157 1528-36. 